\title{
Aerosol particle formation in the upper residual layer
}

\author{
Janne Lampilahti ${ }^{1}$, Katri Leino ${ }^{1}$, Antti Manninen ${ }^{2}$, Pyry Poutanen ${ }^{1}$, Anna Franck ${ }^{1}$, Maija Peltola ${ }^{1}$, Paula Hietala ${ }^{1}$, \\ Lisa Beck $^{1}$, Lubna Dada ${ }^{1}$, Lauriane Quéléver ${ }^{1}$, Ronja Öhrnberg ${ }^{1}$, Ying Zhou ${ }^{3}$, Madeleine Ekblom ${ }^{1}$, Ville Vakkari ${ }^{2,4}$, \\ Sergej Zilitinkevich $^{1,2, \boldsymbol{\dagger}}$, Veli-Matti Kerminen ${ }^{1}$, Tuukka Petäjä ${ }^{1,5}$, and Markku Kulmala ${ }^{1,3,5}$ \\ ${ }^{1}$ Institute for Atmospheric and Earth System Research/Physics, Faculty of Science, University of Helsinki, Helsinki, Finland \\ ${ }^{2}$ Finnish Meteorological Institute, Helsinki, Finland \\ ${ }^{3}$ Aerosol and Haze Laboratory, Beijing Advanced Innovation Center for Soft Matter Science and Engineering, \\ Beijing University of Chemical Technology, Beijing, China \\ ${ }^{4}$ Atmospheric Chemistry Research Group, Chemical Resource Beneficiation, North-West University, \\ Potchefstroom, South Africa \\ ${ }^{5}$ Joint International Research Laboratory of Atmospheric and Earth System Sciences, Nanjing University, Nanjing, China \\ $\mathbf{t}_{\text {deceased, } 15 \text { February } 2021}$
}

Correspondence: Janne Lampilahti (janne.lampilahti@helsinki.fi)

Received: 2 September 2020 - Discussion started: 6 October 2020

Revised: 21 March 2021 - Accepted: 29 March 2021 - Published: 25 May 2021

\begin{abstract}
According to current estimates, atmospheric new particle formation (NPF) produces a large fraction of aerosol particles and cloud condensation nuclei in the Earth's atmosphere, which have implications for health and climate. Despite recent advances, atmospheric NPF is still insufficiently understood in the lower troposphere, especially above the mixed layer (ML). This paper presents new results from colocated airborne and ground-based measurements in a boreal forest environment, showing that many NPF events ( $\sim 42 \%)$ appear to start in the topmost part of the residual layer (RL). The freshly formed particles may be entrained into the growing mixed layer (ML) where they continue to grow in size, similar to the aerosol particles formed within the ML. The results suggest that in the boreal forest environment, NPF in the upper RL has an important contribution to the aerosol load in the boundary layer (BL).
\end{abstract}

\section{Introduction}

It has been estimated that atmospheric new particle formation (NPF) is responsible for most of the cloud condensation nuclei (CCN) in the atmosphere (Dunne et al., 2016; Gordon et al., 2017; Pierce and Adams, 2009; Yu and Luo, 2009). Aerosol-cloud interactions, in turn, have important but poorly understood effects on climate (Boucher et al.,
2013). Being a major source of ultrafine aerosol particles in many environments (e.g., Brines et al., 2015; Posner and Pandis, 2015; Salma et al., 2017; Yu et al., 2019), NPF may have implications for human health.

NPF has been observed in various environments and at various altitudes inside the troposphere. The majority of NPF observations come from ground-based measurements (Kerminen et al., 2018; Kulmala et al., 2004), which can be argued to represent NPF within the mixed layer (ML). ML is a type of atmospheric boundary layer (BL) where turbulence uniformly, especially vertically, mixes quantities like aerosol particle concentrations. Measurements from aircraft show that NPF is also common in the upper free troposphere (FT) (e.g., Clarke and Kapustin, 2002; Takegawa et al., 2014). Entrainment of particles formed in the upper FT was identified as an important source of $\mathrm{CCN}$ in the tropical BL (Wang et al., 2016; Williamson et al., 2019). Measurements from high-altitude research stations also demonstrate that NPF frequently takes place in the FT; in these cases, NPF was often observed in BL air that was transported to the higher altitudes (Bianchi et al., 2016; Boulon et al., 2011; Rose et al., 2017; Venzac et al., 2008).

When studying the vertical distribution of NPF in the lower troposphere, one has to consider the evolution and dynamics of the BL. Nilsson et al. (2001) found that the onset of turbulent mixing correlated better with the onset of NPF at 
ground level than with the increase in solar radiation. The authors gave several hypotheses as to why this might be. One hypothesis was that NPF starts aloft, either in the residual layer (RL) or in the inversion capping the shallow morning ML. As the turbulent mixing starts, the newly formed particles would be transported down and observed at ground level.

Many observations have supported the hypothesis put forward by Nilsson et al. (2001). Größ et al. (2018), Meskhidze et al. (2019) and Stanier et al. (2004) reported positive correlation between the onset of NPF at ground level and the breakup of the morning inversion due to beginning of convective mixing. Chen et al. (2018), Platis et al. (2015) and Siebert et al. (2004) used in situ airborne measurements and observed that NPF started during the morning on the top of a shallow ML capped by a temperature inversion at a few hundred meters above ground. The particles grew to detectable nucleation mode (sub-25 nm) sizes aloft, and when the ML began to grow due to thermally driven convection, the particles were mixed downwards and observed at ground level where they further continued to grow in size. Stratmann et al. (2003) observed newly formed particles inside the RL disconnected from the shallow ML or the inversion that capped it. Furthermore, Wehner et al. (2010) observed that NPF inside the RL was connected to turbulent layers. On the other hand, Junkermann and Hacker (2018) attributed their observations of elevated ultrafine particle layers at a few hundred meter altitudes in the RL to flue gas emissions from smokestacks with subsequent chemistry taking place during air mass transport over long distances.

The hypothesis proposed by Nilsson et al. (2001) was based on observations done in Hyytiälä, Finland, which is a rural site surrounded by boreal forests and with very clean air. However, the supporting evidence comes from measurements done in more polluted environments in Central Europe and the USA. Airborne measurements done over Hyytiälä have not found NPF on top of the shallow morning ML or within the bulk of the RL; instead, the NPF events seem to start within the ML (Boy et al., 2004; Laakso et al., 2007; O'Dowd et al., 2009). This might be because in the more polluted environments there are high enough concentrations of precursor vapors from anthropogenic sources that NPF can be initiated in the morning inversion and/or within the bulk of the RL. Interestingly though, observations from Hyytiälä using a small instrumented airplane have frequently found nucleation mode particle layers above the ML at a much higher altitude range of $\sim 1500-2800 \mathrm{~m}$ above ground and the explanation for these layers is not clear (Leino et al., 2019; Schobesberger et al., 2013; Väänänen et al., 2016). For example, Väänänen et al. (2016) found that for the 2013-2014 airborne measurement campaigns 16/36 ( 44\%) profiles showed an elevated sub- $25 \mathrm{~nm}$ particle layer.

In this study we used co-located airborne and groundbased measurements to study nanoparticles over a boreal forest in Hyytiälä, Finland. We aimed to characterize the elevated nucleation mode particle layers that were a frequent observation in the previous studies. Specifically, we were looking at the following questions: (1) where in terms of atmospheric layers, how often and why do these aerosol particle layer occur? (2) How are they related to ground-based observations and what implications does this have for data interpretation?

\section{Materials and methods}

\subsection{Airborne measurements}

We used data from airborne measurement campaigns conducted between 2011 and 2018 around Hyytiälä, Finland. Here we focused on data within a $40 \mathrm{~km}$ radius from Hyytiälä. Figure 1 shows the data availability from these measurements. Most of the flights were carried out during spring and early autumn because that is when NPF events are most common in Hyytiälä. The measurement setups changed slightly over the years. Detailed descriptions of the setups on board can be found in previous studies (Leino et al., 2019; Schobesberger et al., 2013; Väänänen et al., 2016).

The instrumented aircraft was a Cessna 172 operated from the Tampere-Pirkkala airport (ICAO: EFTP). The sample air was collected through an outside inlet into a main sampling line that was inside the aircraft's cabin. The forward movement of the aircraft during flight provided adequate flow rate inside the main sampling line. The flow rate was maintained at $47 \mathrm{~L} \mathrm{~min}^{-1}$ by using a manual valve. The instruments drew air from the main sampling line using core sampling inlets. The necessary flow rate to the instruments was provided by pumps. The airspeed was kept at $130 \mathrm{~km} \mathrm{~h}^{-1}$ during the measurement flights.

The aerosol instruments on board considered in this study were an ultrafine condensation particle counter (uCPC; TSI, model: 3776 ), measuring the $>3 \mathrm{~nm}$ particle number concentration at a $1 \mathrm{~s}$ time resolution, a particle size magnifier (PSM; Airmodus, model: A10) operated with a TSI 3010 $\mathrm{CPC}$, measuring the $>1.5 \mathrm{~nm}$ particle number concentration at a $1 \mathrm{~s}$ time resolution, and a custom-built scanning mobility particle sizer (SMPS) with a short Hauke-type DMA and a TSI $3010 \mathrm{CPC}$, measuring the aerosol number size distribution in the size range of $10-400 \mathrm{~nm}$. The time resolution of the SMPS was about $2.2 \mathrm{~min}$. In addition, basic meteorological data (temperature, relative humidity and pressure) and water vapor concentration from a Licor Li-840 gas analyzer were used.

Vertically, the measurement profiles extended approximately from 100 to $3000 \mathrm{~m}$ above ground. This altitude range covered the ML, RL and roughly $1 \mathrm{~km}$ of the FT (Fig. 2). The measurement flights lasted about $2-3 \mathrm{~h}$ and were flown mostly during the morning ( 06:00-10:00 UTC) and afternoon ( 11:00-14:00 UTC). Horizontally, the profiles were flown perpendicular to the mean wind in order to avoid the airplane's exhaust fumes. 
(a)

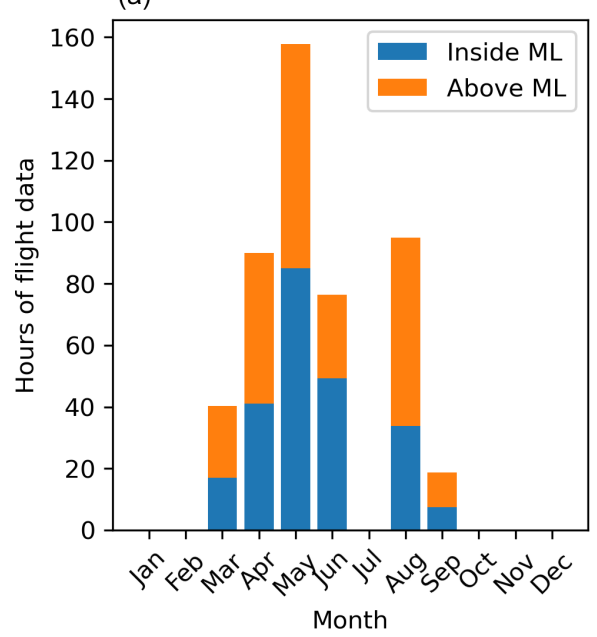

(b)

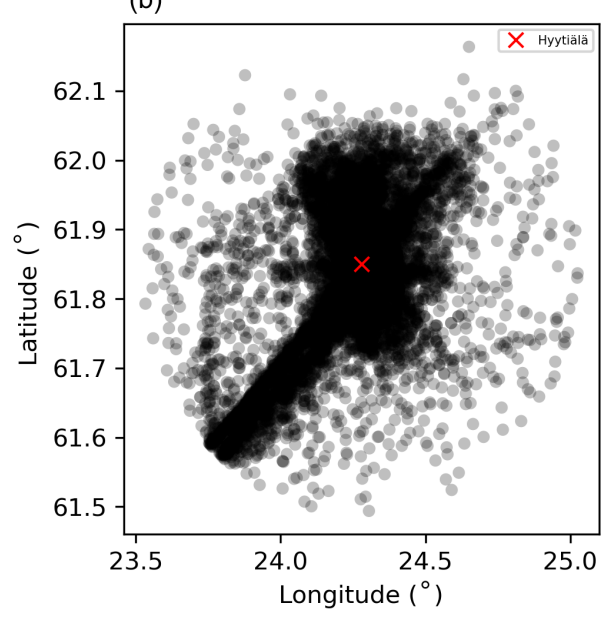

Figure 1. (a) Monthly airborne data availability between 2011-2018 divided into measurements above and below the ML based on the ML height obtained from the ERA5 reanalysis data. (b) Horizontal distribution of the 2011-2018 airborne measurement data. We chose the data within a $40 \mathrm{~km}$ radius from Hyytiälä.

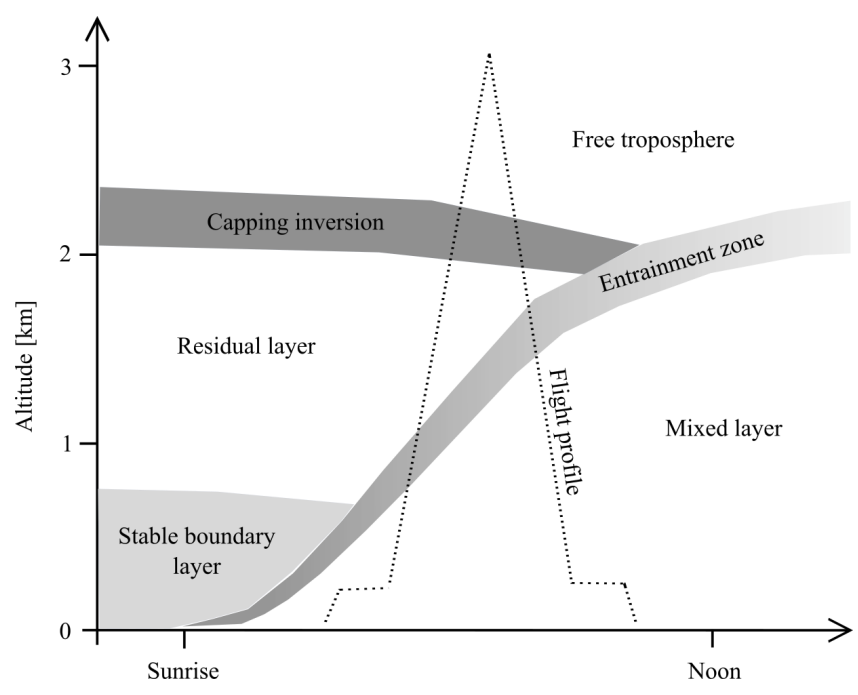

Figure 2. A schematic diagram of an average flight profile in relation to BL evolution.

\subsection{Ground-based measurements}

Comprehensive atmospheric measurements were done at the SMEAR II station in Hyytiälä $\left(61^{\circ} 50^{\prime} 40^{\prime \prime} \mathrm{N}, 24^{\circ} 17^{\prime} 13^{\prime \prime} \mathrm{E}\right.$, $180 \mathrm{~m}$ above sea level (a.s.l.)) since 1996 (Hari and Kulmala, 2005). The landscape around the site is flat and dominated by Scots pine forests with small farms and lakes scattered nearby. The station represents typical rural background conditions.

We used data from the BAECC (Biogenic AerosolsEffects on Clouds and Climate) campaign, which took place in Hyytiälä during February-September 2014 (Petäjä et al., 2016), to study the relationship between BL evolution and
NPF observed at the station. High spectral resolution lidar (HSRL) measurements and meteorological balloon soundings released every $4 \mathrm{~h}$ by the U.S. Department of Energy ARM mobile facility allowed us to monitor the evolution of the BL (Nikandrova et al., 2018).

From the HSRL data we looked at the values of backscatter cross section in order to see the development of the ML during the day. The data were averaged into $30 \mathrm{~m}$ altitude bins and $10 \mathrm{~min}$ temporal bins. The ground-based measurements during the BAECC campaign were also supplemented by aircraft measurements using the instrumented Cessna. In the case of missing soundings, we also looked at the balloon soundings released from Jokioinen $\sim 120 \mathrm{~km}$ southwest from Hyytiälä (WMO: 02963).

The number size distribution of aerosol particles between 3 and $1000 \mathrm{~nm}$ was measured at the station using a differential mobility particle sizer (DMPS; Aalto et al., 2001). A neutral cluster and air ion spectrometer (NAIS; Airel Ltd.; Mirme and Mirme, 2013) measured the number size distribution of air ions and particles in the size ranges of 0.8-42 and 2-42 nm, respectively (Manninen et al., 2009). The time resolutions of the DMPS and NAIS were 10 and $4 \mathrm{~min}$, respectively. The vertical flux of particles $>10 \mathrm{~nm}$ was measured by the eddy covariance method from $23 \mathrm{~m}$ above ground, which is a couple of meters above the canopy (Buzorius et al., 2000). The growth rates for aerosol particles were calculated using the lognormal mode fitting method described in Kulmala et al. (2012).

Vertical profiles of horizontal and vertical winds have been measured with a Halo Photonics Stream Line scanning Doppler lidar since year 2016. The Halo Photonics Stream Line is a $1.5 \mu \mathrm{m}$ pulsed Doppler lidar with a heterodyne detector and $30 \mathrm{~m}$ range resolution, and the minimum range of 
the instrument is $90 \mathrm{~m}$ (Pearson et al., 2009). At Hyytiälä, a vertical stare of 12 beams and integration time of $40 \mathrm{~s}$ per beam is scheduled every $30 \mathrm{~min}$, whereas the other scan types operated during the $30 \mathrm{~min}$ measurement cycle were not utilized in this study. The lidar data were corrected for a background noise artifact (Vakkari et al., 2019). The turbulent kinetic energy (TKE) dissipation rate was calculated from the vertical stare according to the method by O'Connor et al. (2010) with a signal-to-noise ratio threshold of 0.001 applied to the data. Data availability is limited by relatively low aerosol concentration at Hyytiälä but the TKE dissipation rate can be retrieved on most days up to the top of the BL.

\section{Results and discussion}

In the airborne measurements we frequently observed a layer of nucleation mode (sub- $25 \mathrm{~nm}$ ) particles above the ML. First we introduce how the phenomenon was observed in the airborne and ground-based measurements using two case studies. Then we show that sub- $25 \mathrm{~nm}$ particle layers occurred in the topmost part of the RL by studying the average vertical profile of the particle number size distribution and temperature from the airplane. Then we associate the nucleation mode particles in the upper RL to a specific signal in the ground-based measurements and use the observations at the SMEAR II station to gather long-term statistics. All times are reported in UTC.

\subsection{Case study: 2 May 2017}

On 2 May 2017, during the measurement airplane's ascent over Hyytiälä, we observed an increased number concentration of 3-10 nm $\left(N_{3-10}\right)$ and $1.5-3 \mathrm{~nm}\left(N_{1.5-3}\right)$ particles, approximately between 1200 and $2000 \mathrm{~m}$ a.s.l. in the top parts of the ML (Fig. 3a). The lower edge of the aerosol particle layer was observed at 12:24. Within the particle layer the maximum $N_{1.5-3}$ was $\sim 5000 \mathrm{~cm}^{-3}$ and $N_{3-10}$ was $\sim 6000 \mathrm{~cm}^{-3}$. Below the particle layer $N_{1.5-3}$ and $N_{3-10}$ were $\sim 3000 \mathrm{~cm}^{-3}$. Above the layer $N_{3-10}$ dropped to $\sim 200 \mathrm{~cm}^{-3}$. This low number concentration indicates that the airplane was measuring above the ML. The $N_{1.5-3}$ dropped to $\sim 2000 \mathrm{~cm}^{-3}$ and further down to $\sim 200 \mathrm{~cm}^{-3}$ during the descent. The temperature inversion and the drop in water vapor concentration indicate that the height of the ML was approximately $2200 \mathrm{~m}$ a.s.l. (Fig. 3b).

The PSM sometimes had problems with increasing background number concentration (measured with a filter in front of the inlet) during ascents, especially above $2 \mathrm{~km}$. In these cases the background number concentration would increase as the altitude was increased. It is unlikely that on this day the $N_{1.5-3}$ layer was caused by this kind of instrumental problem alone because the number concentration decreased above the layer.
During the descent the airplane entered back into the ML at 12:56 and the $N_{1.5-3}$ and $N_{3-10}$ were increased throughout the ML. The $N_{1.5-3}$ was around $4000 \mathrm{~cm}^{-3}$ and $N_{3-10}$ increased from 4000 to around $8000 \mathrm{~cm}^{-3}$ towards the surface. On the same day, an early morning flight before the sunrise was also performed (Fig. 3a). During this flight no elevated aerosol particle layer was observed and the number concentrations were quite uniform with altitude in the different size ranges, staying below $1500 \mathrm{~cm}^{-3}$.

Roughly 10 min after the aerosol particle layer was first observed from the airplane during the ascent, a new particle mode with similar-sized particles (geometric mean mode diameter about $10 \mathrm{~nm}$ ) appeared at ground level at 12:36 (Fig. 3c). This time was estimated from the NAIS measurements. The appearance of this new particle mode was characterized by a negative peak in the vertical particle flux, suggesting that the particles could be mixed down from aloft. The new particle mode continued to grow for several hours despite the air mass moving over Hyytiälä, indicating a large horizontal source area for the particles. At ground level, a new particle mode with lower number concentration coupled with negative particle flux also appeared at around 10:00.

The number concentration of $>3 \mathrm{~nm}$ aerosol particles along the afternoon flight track is shown in Fig. 3d. The particle layer was observed roughly $4 \mathrm{~km}$ north of Hyytiälä. Throughout the flight the particle number concentration was higher in the north compared to the south. To take this horizontal variability into account we only included aerosol data from the northern part of the flight track in Fig. 3a. The particle layer could still appear in the airborne data and later in the ground-based data if the particles were transported from north to south during the measurement period due to a change in wind direction. Wind measurements from the SMEAR II mast at $67.2 \mathrm{~m}$ altitude show that the wind direction changed from 290 to $330^{\circ}$ between 12:00-12:30 (Fig. 3e). The particles were observed at the SMEAR II station right after the wind direction had changed. On the other hand the negative particle flux associated with the appearance of the particles would suggest an elevated source, and in the case of air mass change we would expect to see the particles appear during the change in wind direction, not after it. In any case, it is difficult to say conclusively if the aerosol particle observations on this day were due to vertical or horizontal transport.

The air masses came from the Arctic Ocean over northern Scandinavia. They went over the west coast of Finland where there are known pollution sources; however, in Hyytiälä, the $\mathrm{SO}_{2}$ and $\mathrm{CO}$ levels remained low all day $(\sim 0.025$ and $\sim 115 \mathrm{ppb}$ for $\mathrm{SO}_{2}$ and $\mathrm{CO}$, respectively). Even when the particles were observed at the measurement station, no increase in pollutant concentrations was observed. Pollution released into the nighttime RL from elevated sources such as flue gas stacks would be expected to form layers at lower altitudes, below a few hundred meters. If the pollution is released during daytime, it is expected to be uniformly mixed into the ML and stay like that in the RL (Junkermann and Hacker, 2018). 

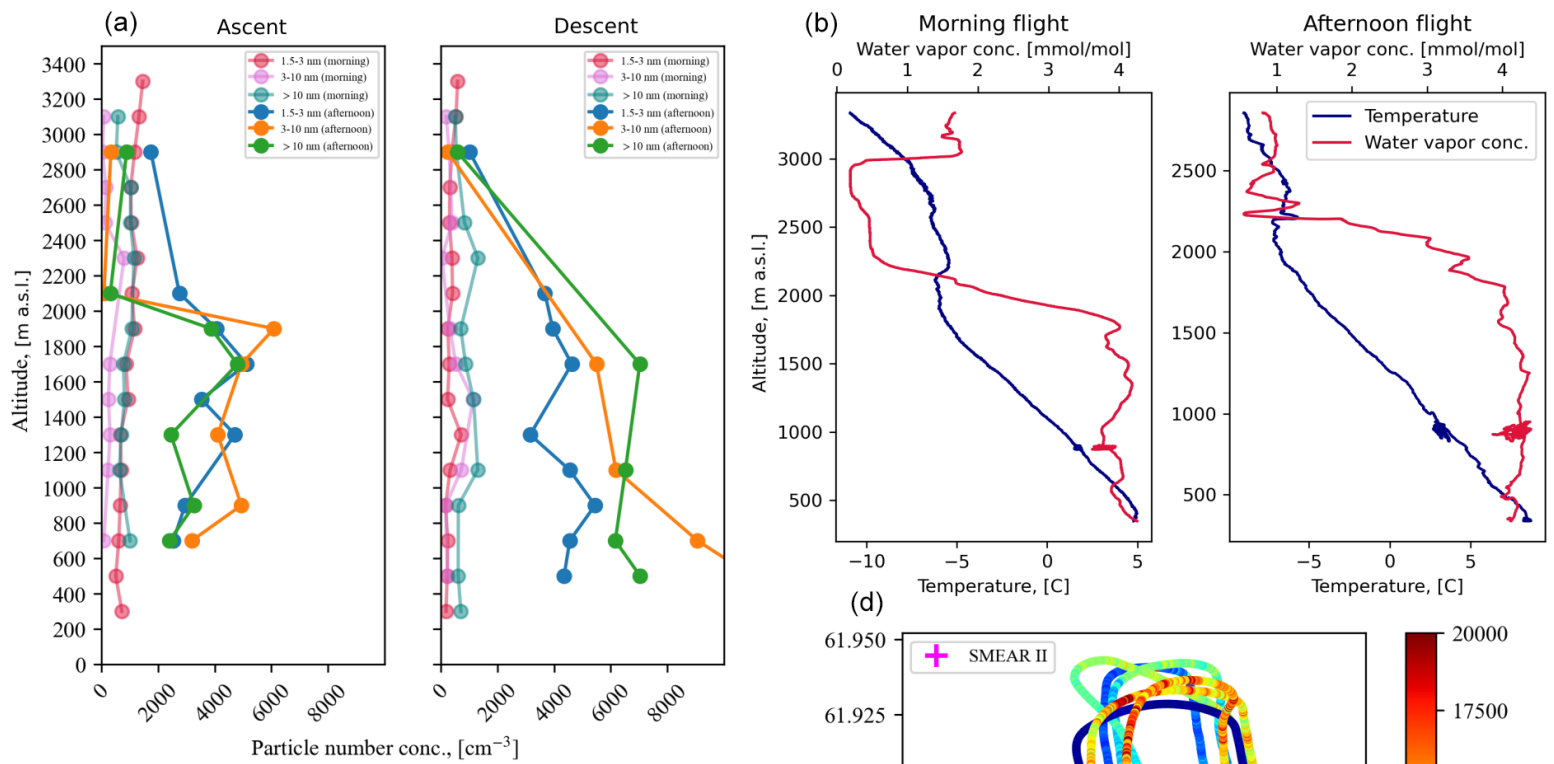

(c) Cessna 172
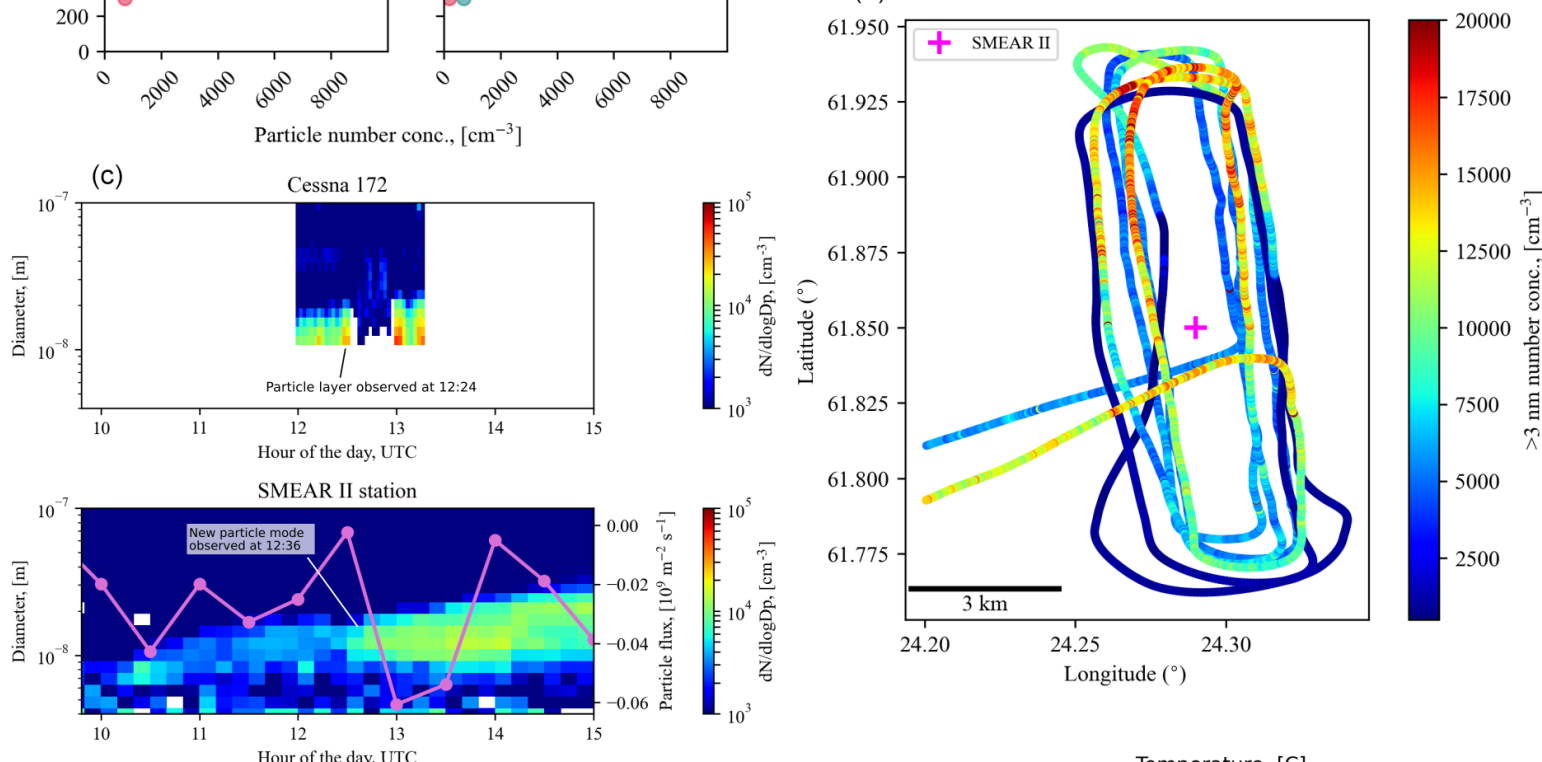

(e)

$67.2 \mathrm{~m}$ above ground
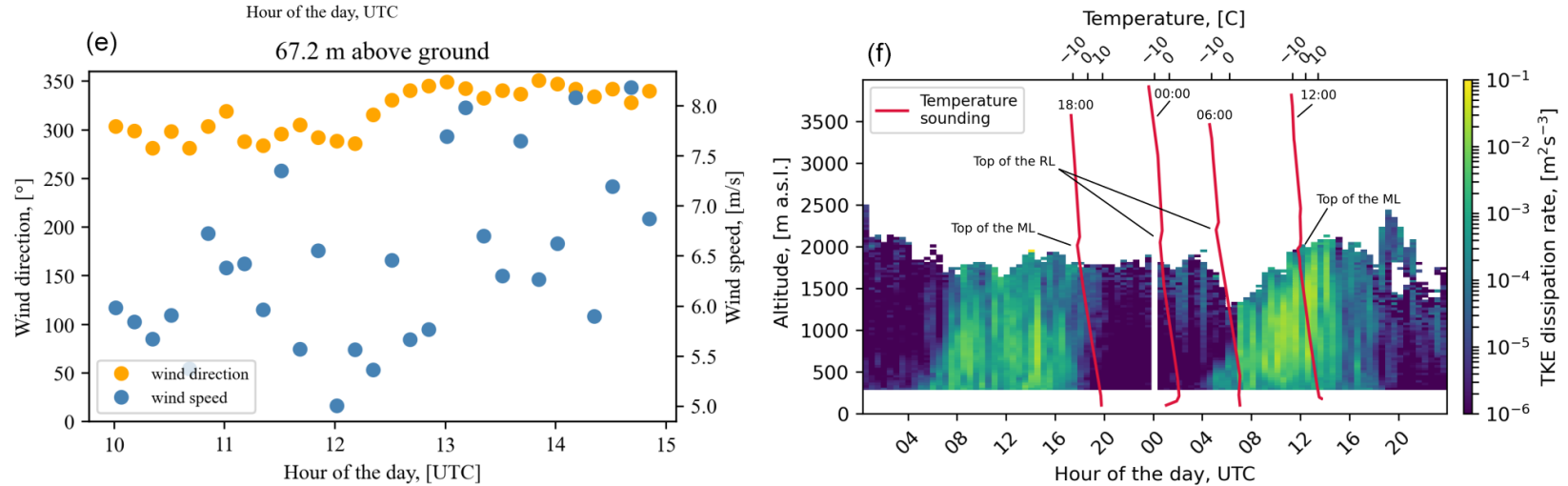

Figure 3. Panel (a) shows vertical profiles of aerosol particle number concentration in three different size ranges (1.5-3, 3-10 and $>10 \mathrm{~nm})$ on 2 May 2017. The data show the morning flight (02:26-03:55 UTC) and the afternoon flight (12:00-13:20 UTC). The profile from the afternoon flight is restricted to the northern part of the flight track $\left(24.25-24.35^{\circ} \mathrm{E}, 61.875-61.95^{\circ} \mathrm{N}\right)$. Panel (b) shows the temperature and water vapor concentration profiles from the morning and the afternoon ascents. Panel (c) shows the particle number size distribution from the measurement airplane and the SMEAR II station. The vertical flux of $>10 \mathrm{~nm}$ particles is superimposed. Negative means downward and positive means upward particle flux. Panel (d) shows the afternoon flight track colored by $>3 \mathrm{~nm}$ particle number concentration. Panel (e) shows the wind speed and direction from the SMEAR II mast (67.2 m). Panel (f) shows the turbulent kinetic energy (TKE) dissipation rate measured by the Doppler lidar in Hyytiälä between 1-2 May 2017. Temperature soundings from Jokioinen are superimposed. 
In order to study the atmospheric layers in the lower troposphere, we plotted the TKE dissipation rate calculated from the Doppler lidar measurements during 1-2 May 2017 and temperature soundings from Jokioinen (Fig. 3f). In the Doppler lidar measurements, the increase in the TKE dissipation rate reveals the development of the ML on both days. On 1 May 2017 the ML reached roughly $1900 \mathrm{~m}$ a.s.1. The temperature sounding at 18:00 shows that this mixed layer was capped by a thermal inversion at about $2000 \mathrm{~m}$ a.s.1. In the two subsequent soundings during the night, the inversion stayed at roughly the same altitude and marked the top of the RL. In the temperature sounding on 2 May 2017 at 12:00 only one inversion is observed at about $1900 \mathrm{~m}$ a.s.l., suggesting that at this point the RL was already mixed into the growing ML. The lidar measurement agrees that on 2 May 2017 the ML reached $1900 \mathrm{~m}$ a.s.1. around 12:00. About $25 \mathrm{~min}$ later the aerosol particle layer was observed from the Cessna. These observations are supported by the temperature and water vapor profiles measured on board the Cessna during the morning and afternoon flights (Fig. 3b).

\subsection{Case study: 19 May 2018}

On 19 May 2018 a similar case was observed. Figure 4a shows that during the airplane's ascent, the lower edge of the particle layer was observed at $\sim 1200 \mathrm{ma}$ a.s.l. and the top of the layer was at $2000 \mathrm{~m}$ a.s.1. The $\mathrm{N}_{3-10}$ increased in the layer from $\sim 1000$ up to $\sim 10000 \mathrm{~cm}^{-3}$. When the airplane descended back into the ML the $N_{3-10}$ was increased to around $6000 \mathrm{~cm}^{-3}$ throughout the ML. The temperature and water vapor measurements show that a well-mixed layer was capped by inversion at $2000 \mathrm{~m}$ a.s.1. (Fig. 4b). Unfortunately the PSM was not working during this flight.

Figure $4 \mathrm{c}$ shows that horizontally the particle layer was observed approximately $5 \mathrm{~km}$ west of the SMEAR II station. When the airplane entered back into the ML, the particle number concentration was increased over the SMEAR II station and in the west part of the measurement area. The aircraft only flew $\sim 2 \mathrm{~km}$ east of the SMEAR II station before turning southwest towards the airport, so it is unclear if the number concentration was increased in the east as well. There was no appreciable change in wind direction, which was from the north during the measurement period (Fig. 4d). Therefore it is unlikely that the particles in the layer were horizontally transported to Hyytiälä from west to east.

The air masses arrived from a similar sector as in the 2 May 2017 case (Arctic Ocean over northern Scandinavia). $\mathrm{SO}_{2}$ and $\mathrm{CO}$ concentrations in Hyytiälä remained low during the measurements $\left(\sim 0.05\right.$ and $\sim 127$ ppb for $\mathrm{SO}_{2}$ and $\mathrm{CO}$, respectively).

Figure $4 \mathrm{e}$ shows the particle number size distribution measurements from the measurement airplane and from the field station. The particle layer was observed as an increased number concentrations in the smallest size channels of the SMPS at 09:00 before the airplane flew above the ML. Roughly
20 min later, a similar-sized particle mode appeared in the ground-based data. For this day there were no particle flux data. The new particle mode continued to grow larger inside the ML for several hours.

Figure 4f shows the TKE dissipation rate on 1819 May 2018 from Hyytiälä and temperature soundings from Jokioinen. On 18 May 2018 the ML went up to $2500 \mathrm{~m}$ a.s.1. in Hyytiälä. The Jokioinen soundings show that at 06:00 the top of the RL was at about $1800 \mathrm{~m}$ a.s.l., marked by the subsiding inversion left from the previous day's ML. The top of the particle layer was at approximately $2000 \mathrm{~m}$ a.s.l.

\subsection{Evidence of nanoparticles in the upper RL based on long-term airborne measurements}

In the two case studies above, the aerosol particle layer was associated with the altitude where the top of the RL was. In order to study this connection further, we analyzed the airborne data measured during 2011-2018. In Fig. 5 we plotted the median and 75 th percentile number size distributions measured on board the aircraft as a function of altitude during NPF event days (65 d out of 130 measurement days) between 07:00 and 10:00 UTC. This is the time window when the morning measurement flight was usually done. NPF event days are characterized by a new growing particle mode appearing in the sub-25 nm size range (Dal Maso et al., 2005). If aerosol formation in the upper RL occurs on less than half of the NPF event days, it might not be visible in the median plot but might still appear in the 75th percentile plot.

Interestingly, in the 75th percentile plot a layer of nucleation mode particles is observed at 2500-3000 $\mathrm{m}$ a.s.l. This altitude range is well above the still growing ML at 07:0010:00. We wanted to know if the elevated particle layer was associated with a temperature inversion, since the RL is commonly capped by such an inversion (Stull, 1988). In Fig. 5 we plotted the mean temperature profile from the flights when the $N_{10-25}$ in $2000-3000 \mathrm{~m}$ altitude range exceeded the 75 th percentile $N_{10-25}$ value (18 d).

The temperature profile shows an inversion base at $2500 \mathrm{~m}$ and, on average, this is likely where the top of the RL was. The reason for the unusually deep RL is probably that the NPF event days tend to be sunny spring days and the ML can grow exceptionally high, which also leads to a deep RL. Our finding is in line with previous observations by Schobesberger et al. (2013) who measured nucleation mode particles close to an elevated temperature inversion above the ML on multiple measurement flights over southern Finland. 
(a)
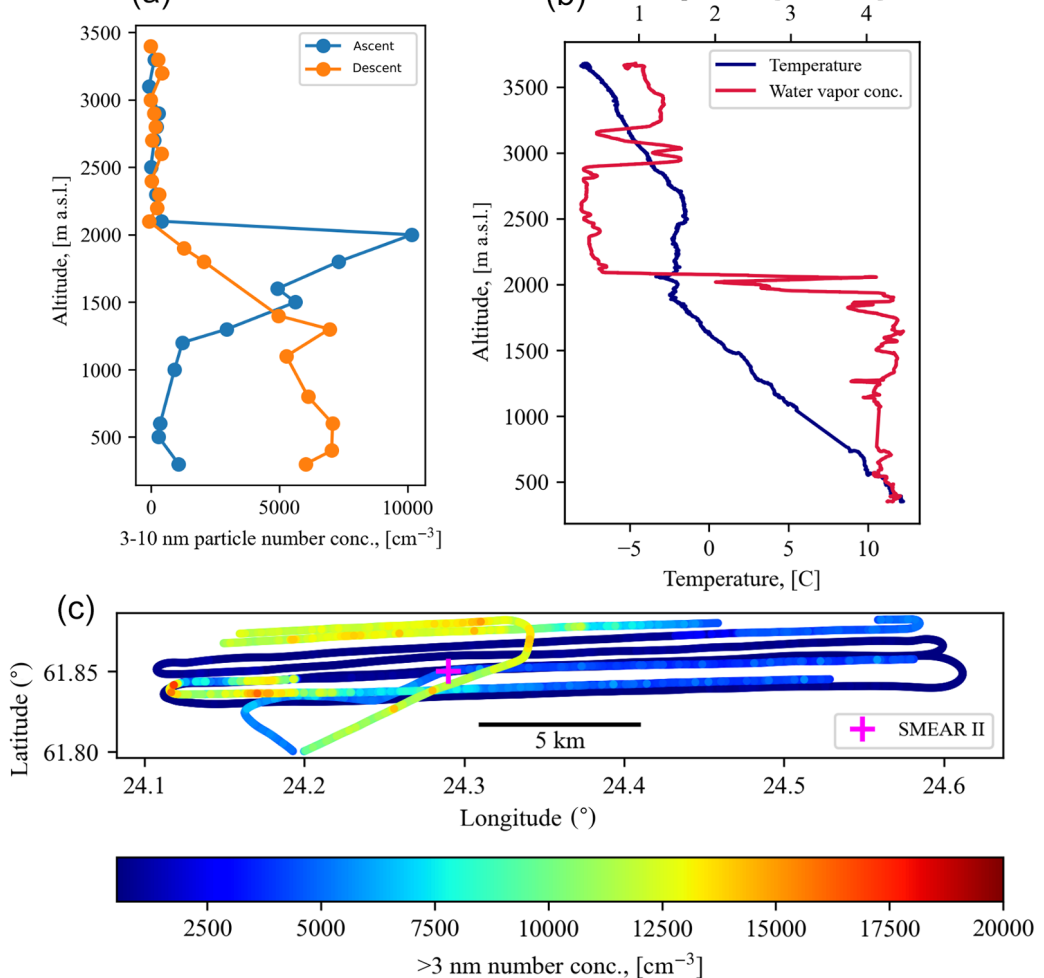

(d)

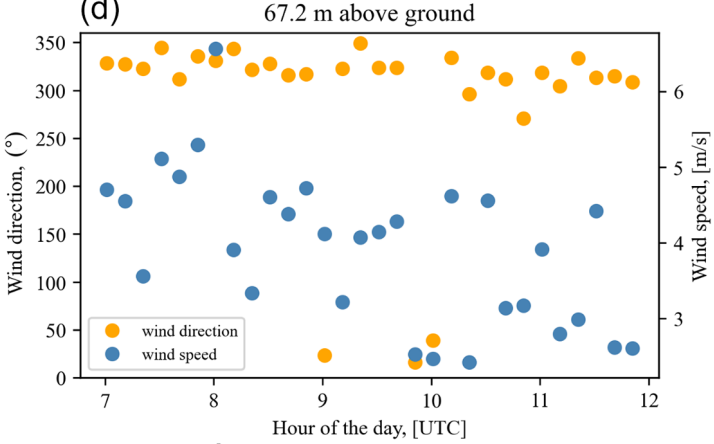

(e)
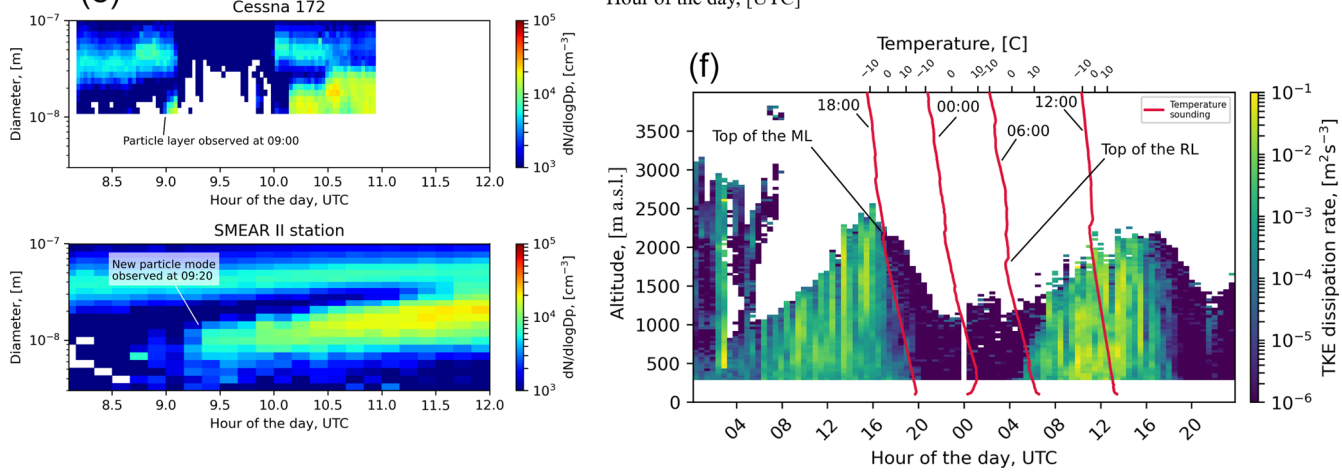

Figure 4. Panel (a) shows vertical profiles of 3-10 nm particle number concentration on 19 May 2017 between 08:42-10:24 UTC. Panel (b) shows the temperature and water vapor concentration profiles during the ascent. Panel (c) shows the afternoon flight track colored by $>3 \mathrm{~nm}$ particle number concentration. Panel (d) shows the wind direction and speed measured from the SMEAR II mast at $67.2 \mathrm{~m}$. Panel (e) shows the particle number size distribution from the measurement airplane and the SMEAR II station. Panel (f) shows the turbulent kinetic energy (TKE) dissipation rate measured by the Doppler lidar in Hyytiälä between 18-19 May 2018. Temperature soundings from Jokioinen are superimposed. 

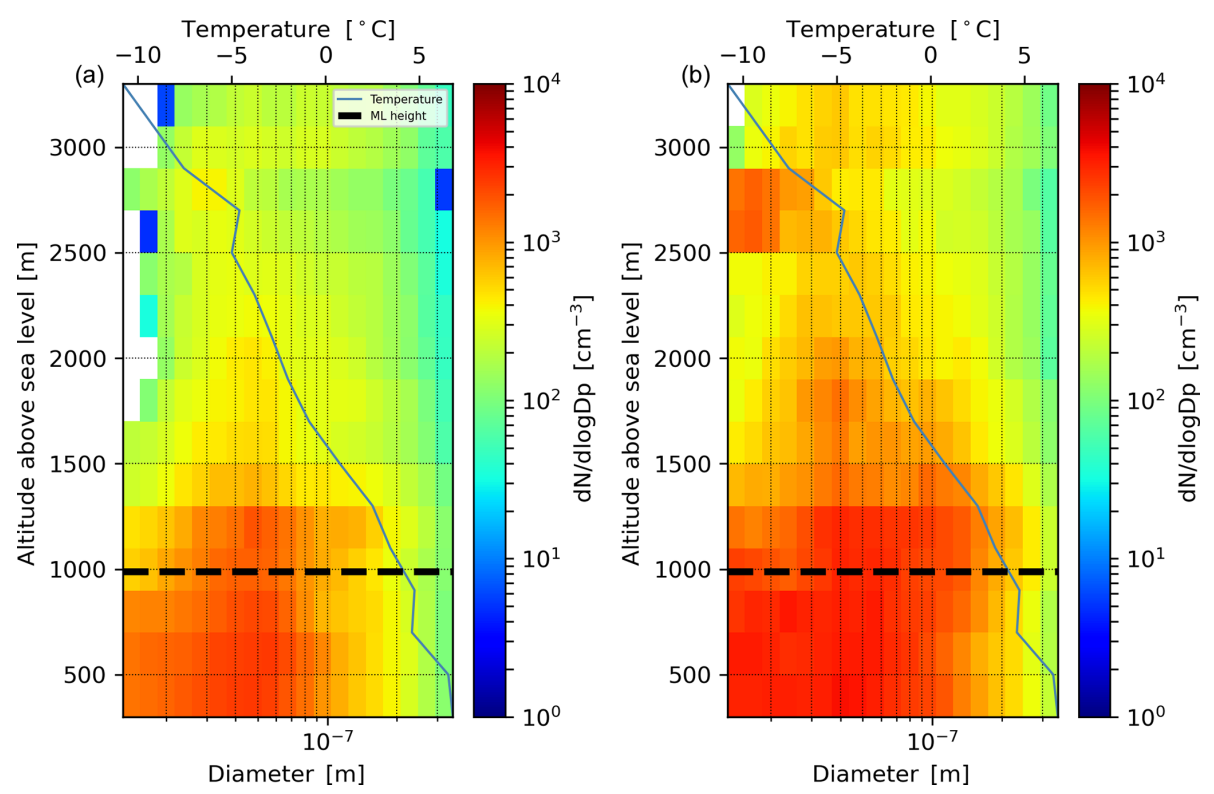

Figure 5. Panel (a) shows the median and (b) the 75th percentile vertical profile of the particle number size distribution measured on board the Cessna on NPF event days between 09:00-12:00 The number size distribution was binned into $200 \mathrm{~m}$ altitude bins. The data are from the campaigns conducted between 2011-2018. The dashed line is the mean ML height obtained from the ERA5 reanalysis data. The blue line shows the mean temperature profile from measurement flights when the sub- $25 \mathrm{~nm}$ number concentration in the $2000-3000 \mathrm{~m}$ altitude range was above the 75 th percentile.

\subsection{Connection between nanoparticles in the upper RL and ground-based observations}

With the BAECC dataset we wanted to investigate whether the sudden appearance of nucleation mode particles with downward particle flux was associated with the ML reaching the upper RL. This would not only further test the hypothesis that the nanoparticles reside in the topmost part of the RL, but also provide us with a condition to identify these events from the ground-based data alone.

We looked for cases where a new particle mode suddenly appeared in the nucleation mode size range during the daytime and the first observation of these particles was associated with a negative peak in particle flux. We noted the times when the particles first appeared and also estimated a confidence interval of the observation. Then we checked if we could find out the height of the RL from balloon soundings or the Cessna flights. We looked for an elevated temperature inversion that was roughly at the same altitude as the previous day's maximum ML height, which was determined from HSRL and/or sounding. We noted the base height of the temperature inversion and took this as the top of the RL. Then we followed the height of the new ML from the HSRL measurements and noted the time when the ML reached the inversion base, also estimating a confidence interval. Figure 6 illustrates an example of this procedure.

We found 8 cases during the campaign where the analysis could be fully carried out and they are summarized in Table 1 . Figure 7 shows a positive correlation between the new particle mode appearance time and the time when the ML reached the top of the RL. This suggests that the suddenly appearing nucleation mode particles were entrained into the ML from the upper RL. We found only a weak positive correlation between the new particle mode appearance time and the geometric mean diameter of particles in the new mode at the moment they were first observed. The mean growth rate of the appearing particle modes was $2.2 \mathrm{~nm} \mathrm{~h}^{-1}$, which is similar to the $2.5 \mathrm{~nm} \mathrm{~h}^{-1}$ reported by Nieminen et al. (2014) for 3-25 nm particles during NPF events in Hyytiälä.

The time that the ML reaches the upper RL depends on the height of the RL, which in turn depends on the height of the ML on the previous day and the rate at which the top of the RL subsides. The mixing time also depends on the rate at which the ML on the day of interest grows. For example, on 28 March 2014 the ML height on the previous day and the RL height during the night were 1300 and $1100 \mathrm{~m}$, respectively. On 4 April 2014 the corresponding numbers were 2800 and $2200 \mathrm{~m}$. Because of this, on 28 March 2014 the ML reached the upper RL much earlier at $\sim 07: 00$ compared to 4 April 2014 when the ML reached the upper RL at $\sim$ 11:00. For example, on 15 April 2014 the ML grew slowly in the morning due to presence of low clouds that limited convection. Because of this, the ML reached the top of the RL relatively late at 13:00.

In a well-mixed layer we would expect the entrained particles to reach the surface in less than an hour (Stull, 1988). If the BL was stratified, the particles could reach the surface at very different rates, which might significantly distort the re- 


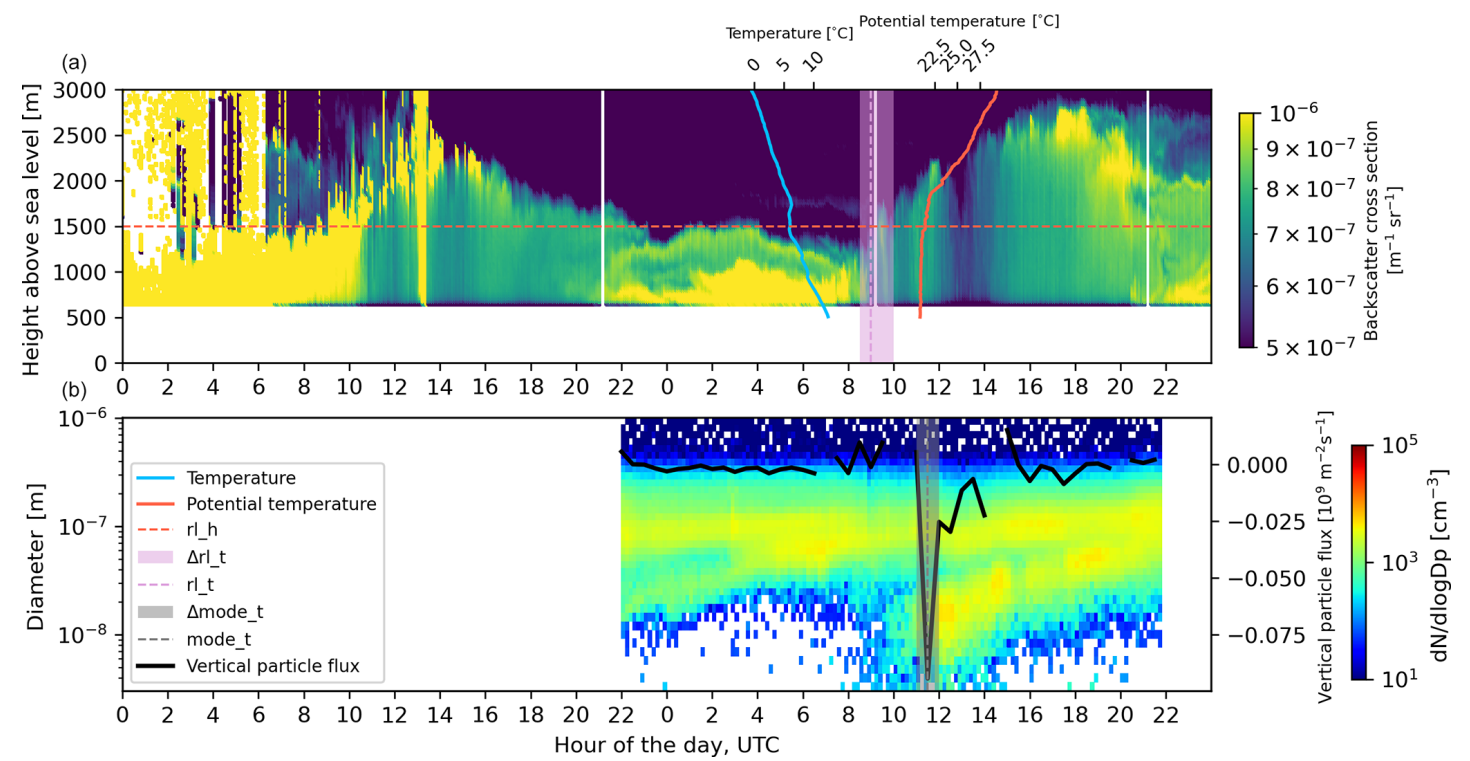

Figure 6. Panel (a) shows the backscatter cross section measured by the HSRL on 4-5 June 2014. The development of the ML is visible from the backscatter cross section signal. Temperature and potential temperature from soundings released in Hyytiälä at 05:20 and 11:20 on 5 June 2014, respectively, are superimposed. The horizontal line rl_h refers to the height of the inversion base in the sounding (height of the RL). The rl_t and $\Delta \mathrm{rl} \_\mathrm{t}$ refer to the time when the ML was estimated to reach the rl_h and the confidence interval for this time, respectively. Panel (b) shows the particle number size distribution measured at the SMEAR II station, the black line is the vertical particle flux. The mode_t and $\Delta$ mode_t, respectively, refer to the time and the confidence interval when a nucleation particle mode that is associated with downward particle flux suddenly appears.

Table 1. Summary of the BAECC dataset analysis. $r l \_h=$ residual layer height during night or early morning ( $\mathrm{m}$ a.s.l.), $\mathrm{rl} \_$ht $=$time when the rl_h was observed (time when the sounding was released, hour of the day, UTC), mode_t $=$ nucleation mode particle mode first appears (hour of the day, UTC), mode_t1/mode_t2 = nucleation mode particle mode appearance confidence interval (hour of the day, UTC), rl_t $=$ new mixed layer reaches the top of the residual layer (hour of the day, UTC), rl_t $1 / \mathrm{rl} \_\mathrm{t} 2=$ new mixed layer reaches the top of the residual layer confidence interval (hour of the day, UTC), bl_h = observed maximum height of the previous day's boundary layer $(\mathrm{m}$ a.s.1.), dp $=$ mean mode diameter for the newly appeared particle mode, when they first appear $(\mathrm{nm})$, gr = growth rate calculated for the newly appeared particle mode $\left(\mathrm{nm} \mathrm{h} \mathrm{h}^{-1}\right), \mathrm{pf}=$ the value of the negative particle flux peak $\left(10^{9} \mathrm{~m}^{-2} \mathrm{~s}^{-1}\right)$.

\begin{tabular}{|c|c|c|c|c|c|c|c|c|c|c|c|c|}
\hline $\begin{array}{l}\text { Date } \\
\text { (yyyymmdd) }\end{array}$ & rl_ht & rl_h & mode_t1 & mode_t & mode_t 2 & rl_t1 & rl_t & rl_t2 & $\mathrm{dp}$ & bl_h & $\mathrm{pf}$ & gr \\
\hline 20140328 & 5.3 & 1100 & 8.5 & 9 & 9.5 & 5.5 & 7 & 8 & 20 & 1300 & -0.25 & 2.28 \\
\hline 20140331 & 7.6 & 2400 & 14 & 14.5 & 15 & 12 & 13.5 & 14 & 10 & 2200 & -0.06 & 2.1 \\
\hline 20140404 & 8.5 & 2200 & 10.5 & 11 & 11.5 & 10.5 & 11 & 11.5 & 8 & 2800 & -0.04 & 1.39 \\
\hline 20140409 & 5.5 & 1500 & 9 & 9.25 & 9.5 & 6 & 6.5 & 7 & 8 & 1800 & -0.13 & 1.18 \\
\hline 20140415 & 5.3 & 1600 & 14.5 & 14.25 & 15 & 12 & 13 & 14 & 11 & 1700 & -0.18 & 1.94 \\
\hline 20140422 & 0.0 & 1800 & 12 & 12.5 & 13 & 10.5 & 11 & 11.5 & 17 & 1900 & -0.17 & 1.0 \\
\hline 20140518 & 0.0 & 1500 & 9.5 & 10 & 10.5 & 8 & 8.5 & 9 & 13 & 1900 & -0.11 & 2.91 \\
\hline 20140705 & 5.3 & 1500 & 11 & 11.5 & 12 & 8.5 & 9 & 10 & 12 & 1700 & -0.1 & 4.83 \\
\hline
\end{tabular}

sults in Fig. 7. The balloon soundings indicate that the MLs in the eight cases were well-mixed since the potential temperature profiles calculated from soundings released around noon and late afternoon were almost constant up to the top of the ML (see example profile in Fig. 6).

\subsection{Proposed explanation for the results}

One possible explanation for the elevated nucleation mode particle layers could be long-range transport coupled with changes in the particle number size distribution such as particle shrinkage. However, it is not clear why such a process would favor the RL-FT interface. If the particle emissions were released into the ML they would likely be distributed more or less uniformly throughout the RL and not be con- 


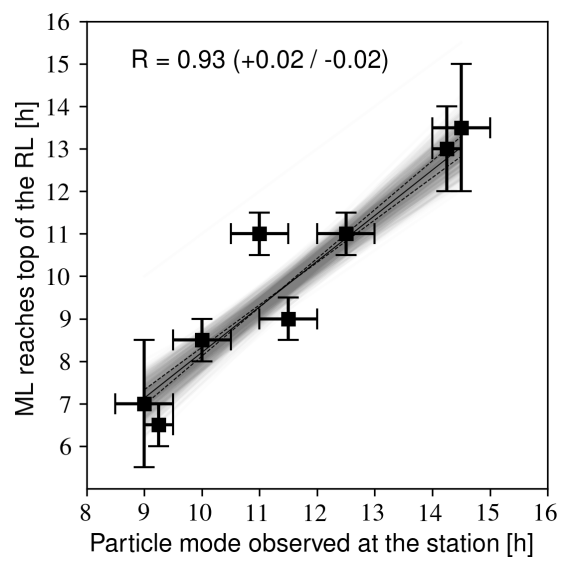

Figure 7. The correlation between the times when a new particle mode coupled with downward particle flux was observed at the field site and the times when the ML reached the top of the RL.

centrated at the top of the RL. If the transported particles subsided from the FT, we would expect to see particle layers at various altitudes in the FT on different days and the layers would not be localized at the top of the RL. We studied the origin of the air masses in the particle layers and found that they were mostly coming from the so-called "clean sector" in the northwest of Hyytiälä (Fig. 8). Apart from during winter months, this sector is associated with non-polluted air and NPF from natural precursors (Tunved et al., 2006).

We find the most likely explanation to be NPF in the upper RL. The gaseous precursors involved in NPF may end up in the upper RL because of mixing from the surface during the previous day (e.g., organic vapors emitted from the forest or sulfuric acid, ammonia and amines originating from human activities) or because of long-range transport in the FT (e.g., iodine oxides from the ocean).

Many factors favor NPF at higher altitudes, including enhanced photochemistry, reduced sinks and reduced temperature. However, the NPF-inducing features of the upper RL would probably be linked to the mixing that takes place in the interface between the RL and FT, since this is where the particle layers seem to be limited. Nilsson and Kulmala (1998) found that mixing two air parcels with different initial temperatures and precursor vapor concentrations can lead to a considerable increase in the nucleation rate. Therefore mixing air from the RL and FT over the inversion, where the precursors are present in one of the layers (most likely the $\mathrm{RL}$ ), could induce aerosol particle formation in the interface layer.

Another possibility is that the RL and the FT contain different precursor vapors that did not initiate nucleation or particle growth on their own; however, when the vapors are mixed in the interface between the two layers NPF occurs. For example, on 2 May 2017 Beck et al. (2021) measured the composition of naturally charged ions using a mass spectrometer on board an aircraft concurrently with our measure-

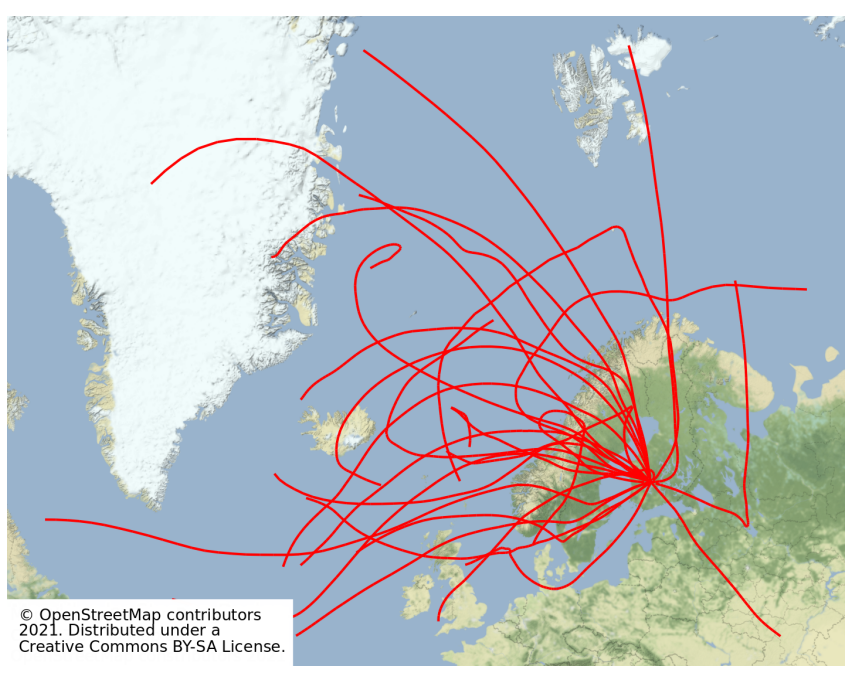

Figure 8. Air mass back trajectories arriving at altitudes over Hyytiälä where nucleation mode particle layers were located based on airborne data and the BAECC data. We calculated the air mass histories for $72 \mathrm{~h}$; however, in the figure some of the trajectories are truncated to fit the map. The trajectories were calculated based on two different conditions. First, based on the BAECC data analysis (Sect. 3.5) such that the air mass arrived at the top of the RL when the ML reached that altitude (see Table 1 for these altitudes and times). Second, based on the vertical profiles between 2011-2018 (Sect. 3.4) such that the back trajectories arrived at $2600 \mathrm{~m}$ altitude at 10:00 UTC on the days when the $N_{10-25}$ in 2000-3000 m altitude range exceeded the 75 th percentile $N_{10-25}$ value.

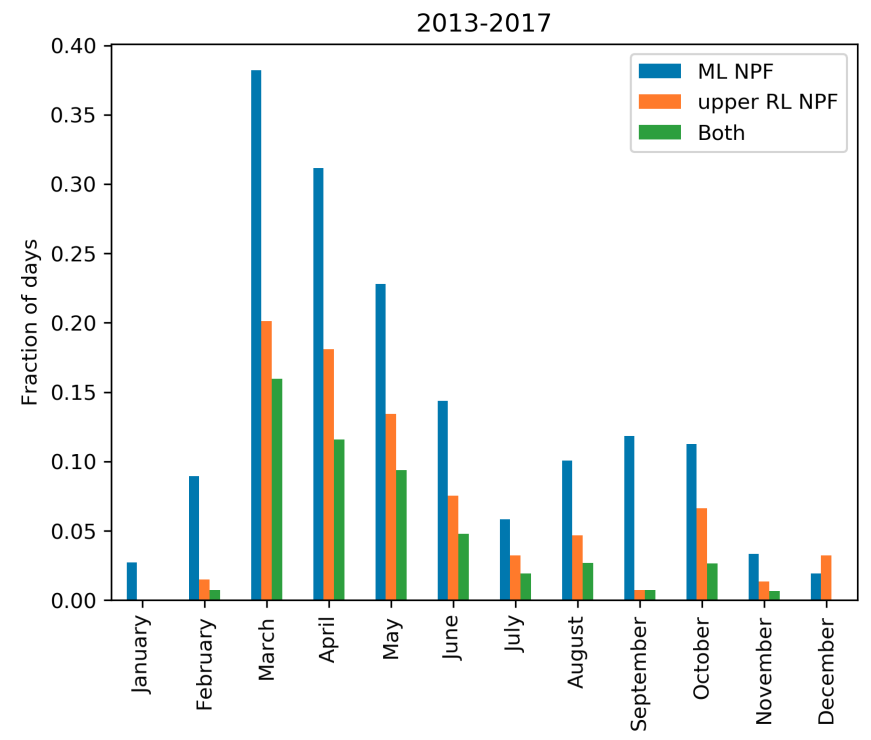

Figure 9. Monthly fractions of NPF within the ML and NPF in the upper RL in Hyytiälä between 2013-2017. 


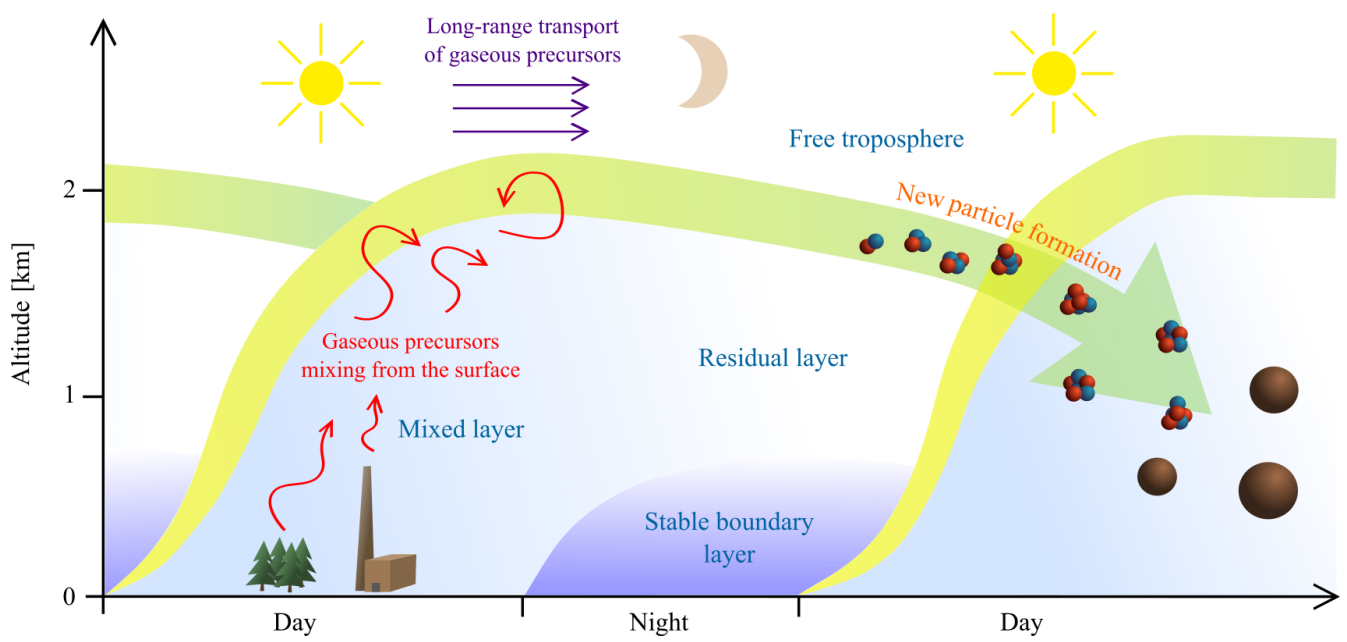

Figure 10. Schematic drawing illustrating the proposed mechanism behind NPF in the upper RL. Gaseous precursors released from biogenic and/or anthropogenic sources are mixed throughout the ML. When the mixing stops during the night the gases are stuck in the RL. Also, gaseous precursors may be transported in the FT. The following morning, photochemistry begins and aerosol particles are formed in the interface between the RL and the FT. The freshly formed particles remain in the elevated layer or get mixed into the a new ML if it reaches the height of the upper RL. The aerosol particles continue to grow larger, contributing to the aerosol load in the BL.

ments. It was found that during the first flight $(\sim 02: 30$ 04:00 UTC) the chemical composition was different in the RL compared to the FT. For example, highly oxygenated molecules (HOMs) as well as iodine containing compounds were present in the RL while methanosulfonic acid (MSA) and sulfuric acid were detected in the FT.

If the growing ML reaches the upper RL, the newly formed particles will be mixed downwards into the ML where they continue to grow in size as low-volatility vapors present in the ML are able to condense onto these particles. The processes are illustrated in Fig. 10. In cases when the particles are not mixed down, they may persist in the FT for a longer time period and possibly have a stronger contribution to cloud formation.

\subsection{Implications for classifying NPF events}

Previous studies that classified NPF events observed in Hyytiälä have collected statistics on the occurrence of suddenly appearing particle modes. Buenrostro Mazon et al. (2009) classified the so-called undefined days between 1996-2006 from Hyytiälä. The undefined days are days that do not fit the NPF event or the nonevent day classes (Dal Maso et al., 2005). One category the authors used was "tail events" where a new particle mode appears at particle diameters greater than $10 \mathrm{~nm}$ and grows for several hours. The authors found that $26 \%$ of NPF events were tail events (assuming that tail events were also NPF events). Dada et al. (2018) collected statistics on "transported events" where an elevated number concentration of 7-25 nm particles persisted for more than $1.5 \mathrm{~h}$, but no elevated number concentrations at smaller particle sizes were observed. It was found that $36 \%$ of the NPF events observed for over 10 years in Hyytiälä were transported events. They occurred especially when the conditions inside the ML were less favorable for nucleation.

Here we found cases in the SMEAR II data between 2013 and 2017 in which a new growing particle mode suddenly, without continuous growth from smallest detectable sizes $(3 \mathrm{~nm})$, appears in the nucleation mode (sub- $25 \mathrm{~nm})$ and is associated with a negative peak in the vertical particle flux (upper RL NPF). We also noted cases where a new particle mode appears with a continuous growth from the smallest detectable sizes (ML NPF). Based on the previous analysis, we assume that in the former case NPF took place in the upper RL and in the latter case inside the ML. The analysis included $1750 \mathrm{~d}$.

The monthly fractions of the different cases are shown in Fig. 8. We found that NPF within the ML occurred on $13 \%(234 / 1750)$ of all days and NPF in the upper RL on $7 \%(117 / 1750)$ of all days. During spring (March-May) the corresponding percentages were $31 \%(132 / 431)$ and $17 \%$ (74/431). On many days NPF took place both in the upper RL and within the ML (4\% or 74/1750 of all days and $12 \%$ or 53/431 of spring days). According to this analysis, NPF in the upper RL constitutes $42 \%(117 / 277)$ of the NPF event days in Hyytiälä.

The monthly distribution of upper RL NPF events follows the distribution of ML NPF events, with a peak during spring (March-May). This is well in line with previous studies that classified NPF events in Hyytiälä (Dal Maso et al., 2005; Nieminen et al., 2014). This makes sense since the conditions favoring ML NPF would also favor upper RL NPF. However, Buenrostro Mazon et al. (2009) and Dada et al. (2018) found 
that the tail events and transported events had a peak during the summer months (June-August).

On $16 \%$ of the NPF event days, NPF only took place in the upper RL but not in the ML. This number is smaller than the $36 \%$ found by Dada et al. (2018) for transported events and the $26 \%$ found by Buenrostro Mazon et al. (2009) for tail events. This might be because we restricted cases to where a negative peak in particle flux was associated with the appearance of nucleation mode particles. For example, a case where the particles were horizontally advected to the measurement site would not be expected to cause a negative peak in the particle flux and therefore would not be classified as upper RL NPF.

\section{Conclusions}

We measured aerosol particles, trace gases and meteorological parameters on board an instrumented Cessna 172 over a boreal forest in Hyytiälä, Finland. The airborne data were complemented by the continuous, comprehensive groundbased measurements at the SMEAR II station.

We found multiple sources of evidence that nanoparticle layers are situated in the topmost part of the RL. Many points would suggest that the particle layers originated from NPF in the upper RL: the particles were in the sub- $25 \mathrm{~nm}$ size range, the air masses originated from a sector northwest of Hyytiälä that is associated with NPF and less pollution during nonwinter months (Tunved et al., 2006), ground-based observations show continuous growth over several hours indicating a large horizontal source area instead of a point source and an increased nucleation rate would be expected to occur in the inversion between RL and FT (Nilsson and Kulmala, 1998). We estimate that such upper RL NPF occurs on $42 \%$ of the NPF event days in Hyytiälä. Our results provide new information on NPF in the BL and they should be taken into account when interpreting and analyzing ground-based as well as airborne measurements of aerosol particles.

Data availability. The particle flux and DMPS data can be accessed from https://avaa.tdata.fi/web/smart/smear (Junninen et al., 2009). The BAECC HSRL and radiosonde data are available from https: //adc.arm.gov/discovery/ (Bambha et al., 2014; Keeler et al., 2014). The Jokioinen soundings can be accessed using the Finnish Meteorological Institute's open data service https://en.ilmatieteenlaitos. fi/open-data (Finnish Meteorological Institute, 2020). The ERA5 dataset can be accessed from https://cds.climate.copernicus.eu/ cdsapp\#!/home (Copernicus Climate Change Service, 2020). The rest of the data were gathered into a dataset that can be accessed from https://doi.org/10.5281/zenodo.4063662 (Lampilahti et al., 2020).
Author contributions. JL, KL, AM, PP, AF, MP, PH, LD and LQ conducted the airborne measurements in 2017. PP wrote processing script for the airborne data. RÖ classified the SMEAR II data for NPF events between 2013-2017. LB, SZ, VMK, TP and MK contributed to the data analysis. YZ and ME analyzed the airborne data between 2011-2018. VV provided the Doppler lidar data. JL prepared the manuscript with contributions from all co-authors.

Competing interests. The authors declare that they have no conflict of interest.

Acknowledgements. This project has received funding from the ERC advanced grant no. 742206, the European Union's Horizon 2020 research and innovation program under grant agreement no. 654109, the Academy of Finland Center of Excellence project No. 272041 and from the Academy of Finland grant 314 798/799. We thank Erkki Järvinen and the pilots at Airspark Oy for operating the research airplane and we are grateful for their hospitality and helpfulness.

Financial support. This research has been supported by the European Research Council (ATM-GTP (grant no. 742206)), the Horizon 2020 (ACTRIS-2 (grant no. 654109)) and the Academy of Finland (grant nos. 314798, 314799 and 272041).

Open-access funding was provided by the Helsinki University Library.

Review statement. This paper was edited by Fangqun Yu and reviewed by three anonymous referees.

\section{References}

Aalto, P., Hämeri, K., Becker, E., Weber, R., Salm, J., Mäkelä, J. M., Hoell, C., O’Dowd, C. D., Hansson, H.-C., Väkevä, M., Koponen, I. K., Buzorius, G., and Kulmala, M.: Physical characterization of aerosol particles during nucleation events, Tellus B, 53, 344-358, https://doi.org/10.3402/tellusb.v53i4.17127, 2001.

Bambha, R., Eloranta, E., Garcia, J., Ermold, B., and Goldsmith, J.: High Spectral Resolution Lidar (HSRL), Atmospheric Radiat. Meas. ARM User Facil., https://doi.org/10.5439/1025200, 2014 (data available at: https://adc.arm.gov/discovery/, last access: 1 October 2020).

Beck, L., Lampilahti, J., Junninen, H., Schobesberger, S., Manninen, A., Leino, K., Quéléver, L., Dada, L., Pullinen, I., Korhonen, F., Bianchi, F., Petäjä, T., Kulmala, M., and Duplissy, J.: Chemical characterisation of negative ions above boreal forest: From ground to free troposphere, in preparation, 2021.

Bianchi, F., Tröstl, J., Junninen, H., Frege, C., Henne, S., Hoyle, C. R., Molteni, U., Herrmann, E., Adamov, A., Bukowiecki, N., Chen, X., Duplissy, J., Gysel, M., Hutterli, M., Kangasluoma, J., Kontkanen, J., Kürten, A., Manninen, H. E., Münch, S., Peräkylä, O., Petäjä, T., Rondo, L., Williamson, C., Weingartner, E., Cur- 
tius, J., Worsnop, D. R., Kulmala, M., Dommen, J., and Baltensperger, U.: New particle formation in the free troposphere: A question of chemistry and timing, Science, 352, 1109-1112, https://doi.org/10.1126/science.aad5456, 2016.

Boucher, O., Randall, D., Artaxo, P., Bretherton, C., Feingold, G., Forster, P., Kerminen, V.-M., Kondo, Y., Liao, H., Lohmann, U., Rasch, P., Satheesh, S. K., Sherwood, S., Stevens, B., and Zhang, X. Y.: Clouds and Aerosols, in: Climate Change 2013: The Physical Science Basis. Contribution of Working Group I to the Fifth Assessment Report of the Intergovernmental Panel on Climate Change, edited by: Stocker, T. F., Qin, D., Plattner, G.-K., Tignor, M., Allen, S. K., Boschung, J., Nauels, A., Xia, Y., Bex, V., and Midgley, P. M., Cambridge University Press, Cambridge, United Kingdom and New York, NY, USA, 571-658, 2013.

Boulon, J., Sellegri, K., Hervo, M., Picard, D., Pichon, J.-M., Fréville, P., and Laj, P.: Investigation of nucleation events vertical extent: a long term study at two different altitude sites, Atmos. Chem. Phys., 11, 5625-5639, https://doi.org/10.5194/acp11-5625-2011, 2011.

Boy, M., Petäjä, T., Dal Maso, M., Rannik, Ü., Rinne, J., Aalto, P., Laaksonen, A., Vaattovaara, P., Joutsensaari, J., Hoffmann, T., Warnke, J., Apostolaki, M., Stephanou, E. G., Tsapakis, M., Kouvarakis, A., Pio, C., Carvalho, A., Römpp, A., Moortgat, G., Spirig, C., Guenther, A., Greenberg, J., Ciccioli, P., and Kulmala, M.: Overview of the field measurement campaign in Hyytiälä, August 2001 in the framework of the EU project OSOA, Atmos. Chem. Phys., 4, 657-678, https://doi.org/10.5194/acp-4657-2004, 2004.

Brines, M., Dall'Osto, M., Beddows, D. C. S., Harrison, R. M., Gómez-Moreno, F., Núñez, L., Artíñano, B., Costabile, F., Gobbi, G. P., Salimi, F., Morawska, L., Sioutas, C., and Querol, X.: Traffic and nucleation events as main sources of ultrafine particles in high-insolation developed world cities, Atmos. Chem. Phys., 15, 5929-5945, https://doi.org/10.5194/acp15-5929-2015, 2015.

Buenrostro Mazon, S., Riipinen, I., Schultz, D. M., Valtanen, M., Dal Maso, M., Sogacheva, L., Junninen, H., Nieminen, T., Kerminen, V.-M., and Kulmala, M.: Classifying previously undefined days from eleven years of aerosol-particle-size distribution data from the SMEAR II station, Hyytiälä, Finland, Atmos. Chem. Phys., 9, 667-676, https://doi.org/10.5194/acp-9667-2009, 2009.

Buzorius, G., Rannik, Ü., Mäkelä, J. M., Keronen, P., Vesala, T., and Kulmala, M.: Vertical aerosol fluxes measured by the eddy covariance method and deposition of nucleation mode particles above a Scots pine forest in southern Finland, J. Geophys. Res.-Atmos., 105, 19905-19916, https://doi.org/10.1029/2000JD900108, 2000.

Chen, H., Hodshire, A. L., Ortega, J., Greenberg, J., McMurry, P. H., Carlton, A. G., Pierce, J. R., Hanson, D. R., and Smith, J. N.: Vertically resolved concentration and liquid water content of atmospheric nanoparticles at the US DOE Southern Great Plains site, Atmos. Chem. Phys., 18, 311-326, https://doi.org/10.5194/acp18-311-2018, 2018.

Clarke, A. D. and Kapustin, V. N.: A Pacific Aerosol Survey. Part I: A Decade of Data on Particle Production, Transport, Evolution, and Mixing in the Troposphere, J. Atmos. Sci., 59, 363-382, https://doi.org/10.1175/15200469(2002)059<0363:APASPI >2.0.CO;2, 2002.
Copernicus Climate Change Service (C3S): ERA5: Fifth generation of ECMWF atmospheric reanalyses of the global climate, Copernicus Climate Change Service Climate Data Store (CDS), available at: https://cds.climate.copernicus.eu/cdsapp\#!/home, last access: 6 May 2017.

Dada, L., Chellapermal, R., Buenrostro Mazon, S., Paasonen, P., Lampilahti, J., Manninen, H. E., Junninen, H., Petäjä, T., Kerminen, V.-M., and Kulmala, M.: Refined classification and characterization of atmospheric new-particle formation events using air ions, Atmos. Chem. Phys., 18, 17883-17893, https://doi.org/10.5194/acp-18-17883-2018, 2018.

Dal Maso, M., Kulmala, M., Riipinen, I., Wagner, R., Hussein, T., Aalto, P. P., and Lehtinen, K. E. J.: Formation and growth of fresh atmospheric aerosols: eight years of aerosol size distribution data from SMEAR II, Hyytiälä, Finland, Boreal Environ. Res., 10, 323-336, 2005.

Dunne, E. M., Gordon, H., Kürten, A., Almeida, J., Duplissy, J., Williamson, C., Ortega, I. K., Pringle, K. J., Adamov, A., Baltensperger, U., Barmet, P., Benduhn, F., Bianchi, F., Breitenlechner, M., Clarke, A., Curtius, J., Dommen, J., Donahue, N. M., Ehrhart, S., Flagan, R. C., Franchin, A., Guida, R., Hakala, J., Hansel, A., Heinritzi, M., Jokinen, T., Kangasluoma, J., Kirkby, J., Kulmala, M., Kupc, A., Lawler, M. J., Lehtipalo, K., Makhmutov, V., Mann, G., Mathot, S., Merikanto, J., Miettinen, P., Nenes, A., Onnela, A., Rap, A., Reddington, C. L. S., Riccobono, F., Richards, N. A. D., Rissanen, M. P., Rondo, L., Sarnela, N., Schobesberger, S., Sengupta, K., Simon, M., Sipilä, M., Smith, J. N., Stozkhov, Y., Tomé, A., Tröstl, J., Wagner, P. E., Wimmer, D., Winkler, P. M., Worsnop, D. R., and Carslaw, K. S.: Global atmospheric particle formation from CERN CLOUD measurements, Science, 354, 1119-1124, https://doi.org/10.1126/science.aaf2649, 2016.

Finnish Meteorological Institute (FMI): Open Data services of the Finnish Meteorological Institute, available at: https://en. ilmatieteenlaitos.fi/open-data, last access: 1 October 2020.

Gordon, H., Kirkby, J., Baltensperger, U., Bianchi, F., Breitenlechner, M., Curtius, J., Dias, A., Dommen, J., Donahue, N. M., Dunne, E. M., Duplissy, J., Ehrhart, S., Flagan, R. C., Frege, C., Fuchs, C., Hansel, A., Hoyle, C. R., Kulmala, M., Kürten, A., Lehtipalo, K., Makhmutov, V., Molteni, U., Rissanen, M. P., Stozkhov, Y., Tröstl, J., Tsagkogeorgas, G., Wagner, R., Williamson, C., Wimmer, D., Winkler, P. M., Yan, C., and Carslaw, K. S.: Causes and importance of new particle formation in the present-day and preindustrial atmospheres, J. Geophys. Res.-Atmos., 122, 8739-8760, https://doi.org/10.1002/2017JD026844, 2017.

Größ, J., Hamed, A., Sonntag, A., Spindler, G., Manninen, H. E., Nieminen, T., Kulmala, M., Hõrrak, U., Plass-Dülmer, C., Wiedensohler, A., and Birmili, W.: Atmospheric new particle formation at the research station Melpitz, Germany: connection with gaseous precursors and meteorological parameters, Atmos. Chem. Phys., 18, 1835-1861, https://doi.org/10.5194/acp18-1835-2018, 2018.

Hari, P. and Kulmala, M.: Station for measuring ecosystematmosphere relations (SMEAR II), Boreal Environ. Res., 10, 315-322, 2005.

Junkermann, W. and Hacker, J. M.: Ultrafine Particles in the Lower Troposphere: Major Sources, Invisible Plumes, and Meteorolog- 
ical Transport Processes, B. Am. Meteorol. Soc., 99, 2587-2602, https://doi.org/10.1175/BAMS-D-18-0075.1, 2018.

Junninen, H., Lauri, A., Keronen, P., AaIto, P., HiItunen, V., Hari, P., and KuImaIa, M.: Smart-SMEAR: on-line data exploration and visualization tool tor SMEAR stations, Boreal Environ. Res., 14, 447-457, 2009 (data available at: https://avaa.tdata.fi/web/smart/ smear, last access: 1 October 2020).

Keeler, E., Coulter, R., Kyrouac, J., and Holdridge, D.: BalloonBorne Sounding System (SONDEWNPN), Atmospheric Radiat. Meas. ARM User Facil., https://doi.org/10.5439/1021460, 2014 (data available at: https://adc.arm.gov/discovery/, last access: 1 October 2020).

Kerminen, V.-M., Chen, X., Vakkari, V., Petäjä, T., Kulmala, M., and Bianchi, F.: Atmospheric new particle formation and growth: review of field observations, Environ. Res. Lett., 13, 103003, https://doi.org/10.1088/1748-9326/aadf3c, 2018.

Kulmala, M., Vehkamäki, H., Petäjä, T., Dal Maso, M., Lauri, A., Kerminen, V.-M., Birmili, W., and McMurry, P. H.: Formation and growth rates of ultrafine atmospheric particles: a review of observations, J. Aerosol Sci., 35, 143-176, https://doi.org/10.1016/j.jaerosci.2003.10.003, 2004.

Kulmala, M., Petäjä, T., Nieminen, T., Sipilä, M., Manninen, H. E., Lehtipalo, K., Dal Maso, M., Aalto, P. P., Junninen, H., Paasonen, P., Riipinen, I., Lehtinen, K. E. J., Laaksonen, A., and Kerminen, V.-M.: Measurement of the nucleation of atmospheric aerosol particles, Nat. Protoc., 7, 1651-1667, https://doi.org/10.1038/nprot.2012.091, 2012.

Laakso, L., Grönholm, T., Kulmala, L., Haapanala, S., Hirsikko, A., Lovejoy, E. R., Kazil, J., Kurten, T., Boy, M., Nilsson, E. D., Sogachev, A., Riipinen, I., Stratmann, F., and Kulmala, M.: Hot-air balloon as a platform for boundary layer profile measurements during particle formation, Boreal Environ. Res., 12, 279-294, 2007.

Lampilahti, J., Leino, K., Manninen, A., Poutanen, P., Franck, A., Peltola, M., Hietala, P., Beck, L., Dada, L., Quéléver, L., Öhrnberg, R., Zhou, Y., Ekblom, M., Vakkari, V., Zilitinkevich, S., Kerminen, V.-M., Petäjä, T., and Kulmala, M.: Aerosol particle formation in the upper residual layer: dataset, Zenodo [data set], https://doi.org/10.5281/zenodo.4063662, 2020.

Leino, K., Lampilahti, J., Poutanen, P., Väänänen, R., Manninen, A., Buenrostro Mazon, S., Dada, L., Franck, A., Wimmer, D., Aalto, P. P., Ahonen, L. R., Enroth, J., Kangasluoma, J., Keronen, P., Korhonen, F., Laakso, H., Matilainen, T., Siivola, E., Manninen, H. E., Lehtipalo, K., Kerminen, V.-M., Petäjä, T., and Kulmala, M.: Vertical profiles of sub-3 nm particles over the boreal forest, Atmos. Chem. Phys., 19, 4127-4138, https://doi.org/10.5194/acp-19-4127-2019, 2019.

Manninen, H. E., Petäjä, T., Asmi, E., Riipinen, N., Nieminen, T., Mikkilä, J., Horrak, U., Mirme, A., Mirme, S., Laakso, L., Kerminen, V.-M., and Kulmala, M.: Long-term field measurements of charged and neutral clusters using Neutral cluster and Air Ion Spectrometer (NAIS), Boreal Environ. Res., 14, 591-605, 2009.

Meskhidze, N., Jaimes-Correa, J. C., Petters, M. D., Royalty, T. M., Phillips, B. N., Zimmerman, A., and Reed, R.: Possible Wintertime Sources of Fine Particles in an Urban Environment, J. Geophys. Res.-Atmos., 124, 13055-13070, https://doi.org/10.1029/2019JD031367, 2019.

Mirme, S. and Mirme, A.: The mathematical principles and design of the NAIS - a spectrometer for the measurement of cluster ion and nanometer aerosol size distributions, Atmos. Meas. Tech., 6, 1061-1071, https://doi.org/10.5194/amt-6-1061-2013, 2013.

Nieminen, T., Asmi, A., Dal Maso, M., Aalto, P. P., Keronen, P., Petäjä, T., Kulmala, M., and Kerminen, V.-M.: Trends in atmospheric new-particle formation: 16 years of observations in a boreal-forest environment, Boreal Environ. Res., 19, 191-214, 2014.

Nikandrova, A., Tabakova, K., Manninen, A., Väänänen, R., Petäjä, T., Kulmala, M., Kerminen, V.-M., and O'Connor, E.: Combining airborne in situ and ground-based lidar measurements for attribution of aerosol layers, Atmospheric Chem. Phys., 18, 10575-10591, https://doi.org/10.5194/acp-18-10575-2018, 2018.

Nilsson, E. D. and Kulmala, M.: The potential for atmospheric mixing processes to enhance the binary nucleation rate, J. Geophys. Res.-Atmos., 103, 1381-1389, https://doi.org/10.1029/97JD02629, 1998.

Nilsson, E. D., Rannik, Ü., Kulmala, M., Buzorius, G., and O'Dowd, C. D.: Effects of continental boundary layer evolution, convection, turbulence and entrainment, on aerosol formation, Tellus B, 53, 441-461, https://doi.org/10.1034/j.16000889.2001.530409.x, 2001.

O'Connor, E. J., Illingworth, A. J., Brooks, I. M., Westbrook, C. D., Hogan, R. J., Davies, F., and Brooks, B. J.: A Method for Estimating the Turbulent Kinetic Energy Dissipation Rate from a Vertically Pointing Doppler Lidar, and Independent Evaluation from Balloon-Borne In Situ Measurements, J. Atmos. Ocean. Tech., 27, 1652-1664, https://doi.org/10.1175/2010JTECHA1455.1, 2010.

O’Dowd, C. D., Yoon, Y. J., Junkermann, W., Aalto, P., Kulmala, M., Lihavainen, H., and Viisanen, Y.: Airborne measurements of nucleation mode particles II: boreal forest nucleation events, Atmos. Chem. Phys., 9, 937-944, https://doi.org/10.5194/acp-9937-2009, 2009.

Pearson, G., Davies, F., and Collier, C.: An Analysis of the Performance of the UFAM Pulsed Doppler Lidar for Observing the Boundary Layer, J. Atmos. Ocean. Tech., 26, 240-250, https://doi.org/10.1175/2008JTECHA1128.1, 2009.

Petäjä, T., O’Connor, E. J., Moisseev, D., Sinclair, V. A., Manninen, A. J., Väänänen, R., von Lerber, A., Thornton, J. A., Nicoll, K., Petersen, W., Chandrasekar, V., Smith, J. N., Winkler, P. M., Krüger, O., Hakola, H., Timonen, H., Brus, D., Laurila, T., Asmi, E., Riekkola, M.-L., Mona, L., Massoli, P., Engelmann, R., Komppula, M., Wang, J., Kuang, C., Bäck, J., Virtanen, A., Levula, J., Ritsche, M., and Hickmon, N.: BAECC: A Field Campaign to Elucidate the Impact of Biogenic Aerosols on Clouds and Climate, B. Am. Meteorol. Soc., 97, 1909-1928, https://doi.org/10.1175/BAMS-D-14-00199.1, 2016.

Pierce, J. R. and Adams, P. J.: Uncertainty in global CCN concentrations from uncertain aerosol nucleation and primary emission rates, Atmos. Chem. Phys., 9, 1339-1356, https://doi.org/10.5194/acp-9-1339-2009, 2009.

Platis, A., Altstädter, B., Wehner, B., Wildmann, N., Lampert, A., Hermann, M., Birmili, W., and Bange, J.: An Observational Case Study on the Influence of Atmospheric Boundary-Layer Dynamics on New Particle Formation, Bound.-Lay. Meteorol., 158, 6792, https://doi.org/10.1007/s10546-015-0084-y, 2015. 
Posner, L. N. and Pandis, S. N.: Sources of ultrafine particles in the Eastern United States, Atmos. Environ., 111, 103-112, https://doi.org/10.1016/j.atmosenv.2015.03.033, 2015.

Rose, C., Sellegri, K., Moreno, I., Velarde, F., Ramonet, M., Weinhold, K., Krejci, R., Andrade, M., Wiedensohler, A., Ginot, P., and Laj, P.: CCN production by new particle formation in the free troposphere, Atmos. Chem. Phys., 17, 1529-1541, https://doi.org/10.5194/acp-17-1529-2017, 2017.

Salma, I., Varga, V., and Németh, Z.: Quantification of an atmospheric nucleation and growth process as a single source of aerosol particles in a city, Atmos. Chem. Phys., 17, 1500715017, https://doi.org/10.5194/acp-17-15007-2017, 2017.

Schobesberger, S., Väänänen, R., Leino, K., Virkkula, A., Backman, J., Pohja, T., Siivola, E., Franchin, A., Mikkilä, J., Paramonov, M., Aalto, P. P., Krejci, R., Petäjä, T., and Kulmala, M.: Airborne measurements over the boreal forest of southern Finland during new particle formation events in 2009 and 2010, Boreal Environ. Res., 18, 145-164, 2013.

Siebert, H., Stratmann, F., and Wehner, B.: First observations of increased ultrafine particle number concentrations near the inversion of a continental planetary boundary layer and its relation to ground-based measurements, Geophys. Res. Lett., 31, L09102, https://doi.org/10.1029/2003GL019086, 2004.

Stanier, C. O., Khlystov, A. Y., and Pandis, S. N.: Nucleation Events During the Pittsburgh Air Quality Study: Description and Relation to Key Meteorological, Gas Phase, and Aerosol Parameters Special Issue of Aerosol Science and Technology on Findings from the Fine Particulate Matter Supersites Program, Aerosol Sci. Tech., 38, 253-264, https://doi.org/10.1080/02786820390229570, 2004.

Stratmann, F., Siebert, H., Spindler, G., Wehner, B., Althausen, D., Heintzenberg, J., Hellmuth, O., Rinke, R., Schmieder, U., Seidel, C., Tuch, T., Uhrner, U., Wiedensohler, A., Wandinger, U., Wendisch, M., Schell, D., and Stohl, A.: New-particle formation events in a continental boundary layer: first results from the SATURN experiment, Atmos. Chem. Phys., 3, 1445-1459, https://doi.org/10.5194/acp-3-1445-2003, 2003.

Stull, R. B.: An Introduction to Boundary Layer Meteorology, Softcover reprint of the original 1st Edn., Springer, Dordrecht, 670 pp., 1988.

Takegawa, N., Moteki, N., Oshima, N., Koike, M., Kita, K., Shimizu, A., Sugimoto, N., and Kondo, Y.: Variability of aerosol particle number concentrations observed over the western Pacific in the spring of 2009, J. Geophys. Res.-Atmos., 119, 1347413488, https://doi.org/10.1002/2014JD022014, 2014.

Tunved, P., Hansson, H.-C., Kerminen, V.-M., Ström, J., Maso, M. D., Lihavainen, H., Viisanen, Y., Aalto, P. P., Komppula, M., and Kulmala, M.: High Natural Aerosol Loading over Boreal Forests, Science, 312, 261-263, https://doi.org/10.1126/science.1123052, 2006.
Väänänen, R., Krejci, R., Manninen, H. E., Manninen, A., Lampilahti, J., Buenrostro Mazon, S., Nieminen, T., Yli-Juuti, T., Kontkanen, J., Asmi, A., Aalto, P. P., Keronen, P., Pohja, T., O'Connor, E., Kerminen, V.-M., Petäjä, T., and Kulmala, M.: Vertical and horizontal variation of aerosol number size distribution in the boreal environment, Atmos. Chem. Phys. Discuss. [preprint], https://doi.org/10.5194/acp-2016-556, in review, 2016.

Vakkari, V., Manninen, A. J., O'Connor, E. J., Schween, J. H., van Zyl, P. G., and Marinou, E.: A novel post-processing algorithm for Halo Doppler lidars, Atmos. Meas. Tech., 12, 839-852, https://doi.org/10.5194/amt-12-839-2019, 2019.

Venzac, H., Sellegri, K., Laj, P., Villani, P., Bonasoni, P., Marinoni, A., Cristofanelli, P., Calzolari, F., Fuzzi, S., Decesari, S., Facchini, M.-C., Vuillermoz, E., and Verza, G. P.: High frequency new particle formation in the Himalayas, P. Natl. Acad. Sci. USA, 105, 15666-15671, https://doi.org/10.1073/pnas.0801355105, 2008.

Wang, J., Krejci, R., Giangrande, S., Kuang, C., Barbosa, H. M. J., Brito, J., Carbone, S., Chi, X., Comstock, J., Ditas, F., Lavric, J., Manninen, H. E., Mei, F., Moran-Zuloaga, D., Pöhlker, C., Pöhlker, M. L., Saturno, J., Schmid, B., Souza, R. A. F., Springston, S. R., Tomlinson, J. M., Toto, T., Walter, D., Wimmer, D., Smith, J. N., Kulmala, M., Machado, L. A. T., Artaxo, P., Andreae, M. O., Petäjä, T., and Martin, S. T.: Amazon boundary layer aerosol concentration sustained by vertical transport during rainfall, $\mathrm{Na}$ ture, 539, 416-419, https://doi.org/10.1038/nature19819, 2016.

Wehner, B., Siebert, H., Ansmann, A., Ditas, F., Seifert, P., Stratmann, F., Wiedensohler, A., Apituley, A., Shaw, R. A., Manninen, H. E., and Kulmala, M.: Observations of turbulenceinduced new particle formation in the residual layer, Atmos. Chem. Phys., 10, 4319-4330, https://doi.org/10.5194/acp-104319-2010, 2010.

Williamson, C. J., Kupc, A., Axisa, D., Bilsback, K. R., Bui, T., Campuzano-Jost, P., Dollner, M., Froyd, K. D., Hodshire, A. L., Jimenez, J. L., Kodros, J. K., Luo, G., Murphy, D. M., Nault, B. A., Ray, E. A., Weinzierl, B., Wilson, J. C., Yu, F., Yu, P., Pierce, J. R., and Brock, C. A.: A large source of cloud condensation nuclei from new particle formation in the tropics, Nature, 574, 399-403, https://doi.org/10.1038/s41586-019-1638-9, 2019.

Yu, F. and Luo, G.: Simulation of particle size distribution with a global aerosol model: contribution of nucleation to aerosol and CCN number concentrations, Atmos. Chem. Phys., 9, 76917710, https://doi.org/10.5194/acp-9-7691-2009, 2009.

Yu, X., Venecek, M., Kumar, A., Hu, J., Tanrikulu, S., Soon, S.-T., Tran, C., Fairley, D., and Kleeman, M. J.: Regional sources of airborne ultrafine particle number and mass concentrations in California, Atmos. Chem. Phys., 19, 14677-14702, https://doi.org/10.5194/acp-19-14677-2019, 2019. 